\title{
GENETIC TRANSFORMATION OF OIL PALM- BASED ON SELECTION WITH HYGROMYCIN
}

\author{
BAHARIAH, B*; RASID, O A*; RAHMAH, A R S*; PARVEEZ, G K A* and MASANI, M Y A*
}

\begin{abstract}
The bar gene conferring resistance to the herbicide Basta was used as a selectable marker in oil palm transformation system. However, the inefficiency in the selection system was believed to generate transgene escape and high rate of chimerism in oil palm. To overcome this limitation, an effective selectable marker for oil palm is required. The aim of this work is to evaluate the use of the hygromycin phosphotransferase (hpt) gene as the selectable marker for generation of stable oil palm transformation via biolistic method and subsequently improve the oil palm transformation efficiency. In this selection approach, the embryogenic calli were bombarded with the vectors carrying the hpt and a green fluorescent protein (gfp) reporter genes, which were driven by the 2X35S promoter assembled in pBINPLUS and pCAMBIA0380 (pPZP) backbones. Visualisation of GFP spots was observed using Fluorescence Microscope for confirmation of successful deoxyribonucleic acid (DNA) delivery. The calli were then cultured on regeneration medium added with hygromycin at $10 \mathrm{mg}$ litre $^{-1}$ and consequently reduced to $5 \mathrm{mg}$ litre $^{-1}$. The presence of transgenes in the bombarded tissue was confirmed by polymerase chain reaction (PCR) amplification of hpt and gfp genes. These results demonstrate the potential of hygromycin as an alternative selection agent for oil palm transformation.
\end{abstract}

Keywords: hygromycin, selectable marker, biolistic.

Received: 30 July 2020; Accepted: 23 October 2020; Published online: 9 December 2020.

\section{INTRODUCTION}

Genetic transformation of oil palm has progressed substantially in the last few decades (Parveez et al., 2015). However, the transformation efficiency is low at $1.5 \%$ by using biolistic (Parveez, 2000), $0.7 \%$ by using Agrobacterium (Masli et al., 2009) and relatively higher at $14 \%$ using oil palm protoplasts by microinjection (Masani et al., 2014) methods, which needs to be further increased. Oil palm is a complicated plant with a long generation cycle, approximately 20-25 years of the economic lifespan (Zulkifli et al., 2018). In producing transgenic material, it has become an important limitation which will require a long term strategy in executing sensitivity, consistency and repeatability tests of the oil palm tissue. Apart from this factor, the development of the effective transformation system, particularly efficient selectable markers for the selection of transformants is being carried out.

\footnotetext{
Malaysian Palm Oil Board,

6 Persiaran Institusi, Bandar Baru Bangi,

43000 Kajang, Selangor, Malaysia.

E-mail: bahariah@mpob.gov.my
}

Initially, the use of herbicide selectable marker, the bar gene, has become an established practice in oil palm genetic transformation. It was first reported as the most efficient selectable marker in oil palm transformation (Parveez et al., 2000; 2007). The bar gene isolated from Streptomyces hygroscopicus (Thompson et al., 1987) was originally used to obtain tolerance to the antibiotic bialaphos and herbicide resistance in plants (De Block et al., 1987). Resistance is conferred by encoding the enzyme phosphinothricin acetyltransferase, which is responsible for detoxifying phosphinothricin (PPT) by acetylation(Murakami etal.,1986).Unfortunately, molecular analysis of the regenerated transgenic oil palm plants using bar selectable marker gene has suggested the presence of chimeric, causing them to survive under selection pressure (escape phenomenon) in majority of the analysed samples. This may be due to the non-optimal and appropriate selection system during the regeneration process of transgenic plants (Nurfahisza et al., 2014; Masura et al., 2017).

Effort has been made to establish an efficient transformation selection system for oil palm by using 
an alternative selectable marker gene, antibiotic hygromycin phosphotransferase (hpt). The hpt gene which was originally derived from E. coli confers resistance to hygromycin B (Gritz and Davies, 1983) that can interfere with translation process and disturb the protein synthesis (Gonzalez et al., 1978). This can be more toxic and kills sensitive cells faster. As a result, it has been widely used as a resistance gene for plant transformation in different species, such as for cassava (Zhang and Puonti-Kaerlas, 2000), castor (Sujatha and Sailaja, 2005), dendrobium (Suwanaketchanatit et al., 2007), grape (Fan et al., 2008), rapeseed (Liu et al., 2011) and spinach (Milojević et al., 2012). The hygromycin antibiotic has also been successfully used as a selection agent in oil palm transformation, but no study has been reported describing the production of stable transformation plants. For instance, Parveez et al. (1996; 2007); Abdullah et al. (2005); Kanchanapoom et al. (2008); Bhore and Shah (2012); Kalawong and Techato (2012) and Fakhrana et al. (2019) showed that the antibiotic, hygromycin is one of the most sensitive selection agents for oil palm. Previous minimal inhibition studies demonstrated that the optimal concentrations of $h p t$ gene varied with developmental stages of tissues. The antibiotic completely inhibited the growth of immature embryos, seedling, mature embryos and embryogenic calli at 8-6 mg litre ${ }^{-1}, 10$ $\mathrm{mg}$ litre $^{-1}, 20 \mathrm{mg}$ litre $^{-1}, 30 \mathrm{mg}$ litre $^{-1}$ and $50 \mathrm{mg}$ litre $^{-1}$, respectively (Table 1).

In this work, we aimed to evaluate the use of antibiotic $h p t$ selectable marker gene to produce stably transformed transgenic oil palm. Thus, as part of the ongoing efforts to develop an oil palm transformation system using the antibiotic hygromycin resistance gene, two expression vectors carrying the $h p t$ selectable marker gene and $g f p$ reporter gene driven by $2 X \mathrm{XaMV} 35 \mathrm{~S}$ promoter in different vector backbones were evaluated in this study. The pBIHA1 vector in pBINPLUS backbone (Belknap et al., 2008) which was previously reported (Bahariah et al., 2017) and a newly constructed vector,
pBIHA-X in pCAMBIA backbone (Hajdukiewicz et al., 1994) were examined for their ability to increase the transgene expression level and develop an efficient oil palm transformation system by using hygromycin selection.

\section{MATERIALS AND METHODS}

\section{Vector Construction}

The plasmids used for construction of pBIHA-X are listed in Table 2. The vector PBIHA-X is based on pCAMBIA0380, a pPZP family (Hajdukiewicz et al., 1994), was constructed by using two intermediate vectors created in a previous study (Bahariah et al., 2017). Plasmid pUC19 (Norrander et al., 1983) served as a vector for cloning DNA fragments. The p2X35STEVGFP-GII $(5.2 \mathrm{~kb})$ and P2X35STEVHPTGII $(5.5 \mathrm{~kb})$ contain $g f p$ gene from pAMCFDV-GFP and $h p t$ gene from pCAMBIA1303, respectively. The genes were controlled by a $0.9 \mathrm{~kb} 2$ X35S promoter derived from the binary vector pTF101.1 (Paz et al., 2004) and cloned in a pGreenII0000 cloning vector. In order to construct $\mathrm{p} 2$ X35SHPTGFP-0380 (pBIHA-X) vector, two deoxyribonucleic acid (DNA) fragments of 2X35S-TEVHPT-35ST and 2X35S-TEVGFP-35ST were ligated to the HindIII and Spe 1 sites of pCAMBIA0380 to create $10810 \mathrm{bp}$ of p2X35STEVHPT-0380 (pBIHA-X).

\section{Plant Materials and Culture Conditions}

The oil palm cultures used in this study were provided by Clonal Propagation Group, MPOB, Malaysia. Young leaflets of P164 ortet sample with a width of approximately $2-3 \mathrm{~mm}$ were cultured on a modified Murashige and Skoog medium, supplemented with 8-10 mg litre ${ }^{-1}$ NAA for callus induction and proliferation (Murashige and Skoog, 1962). They were maintained in the dark with a

\begin{tabular}{|c|c|c|}
\hline Oil palm tissues & General working concentration & References \\
\hline Immature embryos & 20-50 mg litre ${ }^{-1}$ & Parveez et al. (1996) \\
\hline Immature embryos & 20-50 mg litre ${ }^{-1}$ & Abdullah et al. (2005) \\
\hline Immature embryos & $20 \mathrm{mg}$ litre $^{-1}$ & Parveez et al. (2007) \\
\hline $\begin{array}{l}\text { Seedling } \\
\text { Mature embryos } \\
\text { Embryogenic calli }\end{array}$ & $50 \mathrm{mg}$ litre $^{-1}$ & Kanchanapoom et al. (2008) \\
\hline Immature embryos & 8-6 mg litre ${ }^{-1}$ & Bhore and Shah (2012) \\
\hline Embryogenic calli & $30 \mathrm{mg}$ litre $^{-1}$ & Kalawong and Te-chato (2012) \\
\hline Embryogenic calli & $10 \mathrm{mg}$ litre $^{-1}$ & Fakhrana et al. (2019) \\
\hline Embryogenic calli & $5 \mathrm{mg} \mathrm{litre}^{-1}$ & In this study \\
\hline
\end{tabular}


temperature of $28 \pm 1^{\circ} \mathrm{C}$. Friable calli derived from the primary embryoid initiation were then isolated and inoculated in the liquid medium treated with $1 \mathrm{mg}$ litre $^{-1} 2,4-\mathrm{D}$ and $0.1 \mathrm{mg}$ litre $^{-1}$ NAA for culture maintenance (L-1). The embryogenic calli developed from eight months suspension calli were subsequently cultivated on L-1 solidified medium. Approximately $0.5 \mathrm{~g}$ of embryogenic calli with sizes, which ranged from 0.5 to $1.0 \mathrm{~mm}$ per plate, was incubated in the dark at $28^{\circ} \mathrm{C}, 24 \mathrm{hr}$ prior to the bombardment. After bombardment, the embryogenic calli were cultured in L-1 medium with no selection for callus proliferation for four weeks in the dark at $28^{\circ} \mathrm{C}$. The cultures were then transferred onto the selection medium, hormonefree maturation medium (MSB) supplemented with $10 \mathrm{mg}$ litre $^{-1}$ of hygromycin selective agent at $28^{\circ} \mathrm{C}$ in dark condition, then transferred to medium regeneration (EC) under $16 / 8 \mathrm{hr}$ light conditions until shoots developed. The culture medium was changed and subcultured repeatedly every four weeks. After a period of six months, the regenerated shoots were placed on shoot inducing (SI) medium and finally in the rooting medium (Table 3).

\section{Bombardment of Calli with hpt Gene Constructs}

A total of $20 \mu \mathrm{g}$ of the plasmid DNA having $h p t$ gene was precipitated onto $0.6 \mu \mathrm{g}$ gold particles. The DNA coated gold particles were used to bombard oil palm embryogenic callus cultures using the PDS-1000/He Particle Delivery System (Bio-Rad, Hercules, CA USA). Bombardment was carried out at the following conditions; 1100 psi rupture

TABLE 2. PLASMIDS USED IN THIS STUDY

\begin{tabular}{|c|c|c|}
\hline Plasmids & Description & Reference source \\
\hline pBluescriptSK(-) & Cloning vector & Stratagene \\
\hline PCRII TOPO & Cloning vector & Invitrogen \\
\hline pUC19 & Cloning vector & Norrander et al. (1983) \\
\hline pGreenII0000 & Intermediate cloning vector & John Innes Centre \\
\hline pCAMBIA0380 & Binary Ti vector for Agrobacterium-mediated plants transformation & Hajdukiewicz et al. (1994) \\
\hline pAMCFDV-GFP & Contain $m G F P$ reporter gene and $35 S T$ sequences & Masani et al. (2014) \\
\hline pTF101.1 & Contain 2XCaMV35STEV promoter sequence & Paz et al. (2004) \\
\hline pCAMBIA1303 & Contain hygromycin (hptII) gene & Hajdukiewicz et al. (1994) \\
\hline p2X35STEVGFP-GII & Intermediate cloning vector & Bahariah et al. (2017) \\
\hline p2X35STEVHPT-GII & Intermediate cloning vector & Bahariah et al. (2017) \\
\hline
\end{tabular}

TABLE 3. MEDIA COMPOSITION FOR SELECTION AND REGENERATION OF TRANSGENIC OIL PALM

\begin{tabular}{|c|c|c|c|c|c|}
\hline \multirow{2}{*}{ Component } & \multicolumn{4}{|c|}{ Medium } & \multirow[b]{2}{*}{ Rooting } \\
\hline & L-1 & MSB & EC & SI & \\
\hline $\mathrm{M}+\mathrm{S}$ Macro $\left(\mathrm{ml}\right.$ litre $\left.^{-1}\right)$ & 50 & 50 & 50 & 50 & 50 \\
\hline $\mathrm{M}+\mathrm{S}$ Micro (ml litre $\left.{ }^{-1}\right)$ & 10 & 10 & 10 & 10 & 10 \\
\hline Y3 Vits (ml litre ${ }^{-1}$ ) & 1 & 1 & 1 & 1 & 1 \\
\hline NaFeEDTA $\left(\mathrm{g}\right.$ litre $\left.^{-1}\right)$ & 0.0375 & 0.0375 & 0.0375 & 0.0375 & 0.0375 \\
\hline Myo-inositol (g litre ${ }^{-1}$ ) & 0.1 & 0.1 & 0.1 & 0.1 & 0.1 \\
\hline L-Glutamine (g litre ${ }^{-1}$ ) & 0.1 & 0.1 & 0.1 & 0.1 & 0.3 \\
\hline L-Arginine (g litre ${ }^{-1}$ ) & - & 0.1 & 0.1 & 0.1 & - \\
\hline L-Asparagine (g litre ${ }^{-1}$ ) & - & 0.1 & 0.1 & 0.1 & - \\
\hline $\operatorname{NAA}(\mu \mathrm{M})$ & 0.1 & - & 0.5 & 0.1 & 9.0 \\
\hline $2,4-\mathrm{D}(\mu \mathrm{M})$ & 1.0 & - & - & - & - \\
\hline Activated charcoal $(\%)$ & - & - & - & - & 0.25 \\
\hline Plant agar (g litre ${ }^{-1}$ ) & 8 & 8 & 8 & 8 & - \\
\hline Sucrose $\left(\mathrm{g}\right.$ litre $\left.^{-1}\right)$ & 30 & 30 & 30 & 30 & 60 \\
\hline $\mathrm{pH}$ & 5.7 & 5.7 & 5.7 & 5.7 & $5.7-6.0$ \\
\hline Antibiotic hygromycin (mg litre $\left.{ }^{-1}\right)$ & - & - & 10 & 5 & 5 \\
\hline
\end{tabular}

Note: L-1 - proliferation medium; MSB - maturation medium; EC - regeneration medium: callus to shoot; SI - regeneration medium: shoots elongation; NAA - $\alpha$-napthaleneacetic acid. 
disc pressure, $6 \mathrm{~mm}$ rupture disc to macrocarrier distance, $11 \mathrm{~mm}$ macrocarrier to stopping plate distance, $75 \mathrm{~mm}$ stopping plate to target tissue distance and $67.5 \mathrm{~mm} \mathrm{Hg}$ vacuum pressure (Parveez, 2000). Thirty to 40 replications were carried out. The experiment was repeated seven times with several modifications. After bombardment, the calli were observed for GFP expression at $24 \mathrm{hr}$ and two weeks after bombardment, using Nikon AZ100 fluorescence microscope multizoom microscope equipped with specific GFP filter. The GFP signals provided an internal reference for the identification of successfully transformed tissues. The cultures were then incubated at $28^{\circ} \mathrm{C}$ under $16 / 8 \mathrm{hr}$ light conditions. The culture medium was changed at every four weeks interval.

\section{Polymerase Chain Reaction (PCR) Analysis}

Transformed embryoids that survived on hygromycin selection media were assessed and compared with wild type by PCR analysis. PCR amplification was carried out in a $25 \mu \mathrm{l}$ reaction mixture, containing $100 \mathrm{ng}$ of DNA template, 10 $\mu \mathrm{M}$ of each primer (reverse and forward primers flanking the $h p t$ gene), $12.5 \mu \mathrm{l}$ of 2 XGoTaq ${ }^{\circledR}$ Green
Master Mix (Promega) and nuclease-free water to a final volume of $25 \mu \mathrm{l}$. The PCR amplifications carried out were as follows: initial denaturation $\left(98^{\circ} \mathrm{C}\right.$ for $\left.1 \mathrm{~min}\right)$, denaturation $\left(98^{\circ} \mathrm{C}\right.$ for $\left.5 \mathrm{sec}\right)$, annealing $\left(67^{\circ} \mathrm{C}\right.$ for $\left.5 \mathrm{sec}\right)$, extension $\left(72^{\circ} \mathrm{C}\right.$ for 1 $\mathrm{min})$ and elongation $\left(72^{\circ} \mathrm{C}\right.$ for $\left.1 \mathrm{~min}\right)$. The putative transformed samples were further analysed by PCR for detection of $g f p$ transgene using mGFP1 F/R primers. The sequences of reverse and forward primers of hpt and $g f p$ genes are listed in Table 4. The PCR products were electrophoresed in a 1.0\% agarose gel at $110 \mathrm{~V}$ for $80 \mathrm{~min}$.

\section{RESULTS AND DISCUSSION}

In order to investigate the potential use of hpt gene for selection of hygromycin resistant transgenic plants, two vectors namely pBIHA-X (10 $810 \mathrm{bp})$ in pCAMBIA0380 backbone, which was successfully constructed in this study and pBIHA1 (14 194 bp) in pBINPLUS backbone which was previously reported (Bahariah et al., 2017) were evaluated in this study (Figure 1).

The pBIHA-X (p2X35SHPTGFP-0380) plasmid was constructed to contain the hpt selectable marker and $g f p$ reporter genes driven by 2 XCaMV35S in

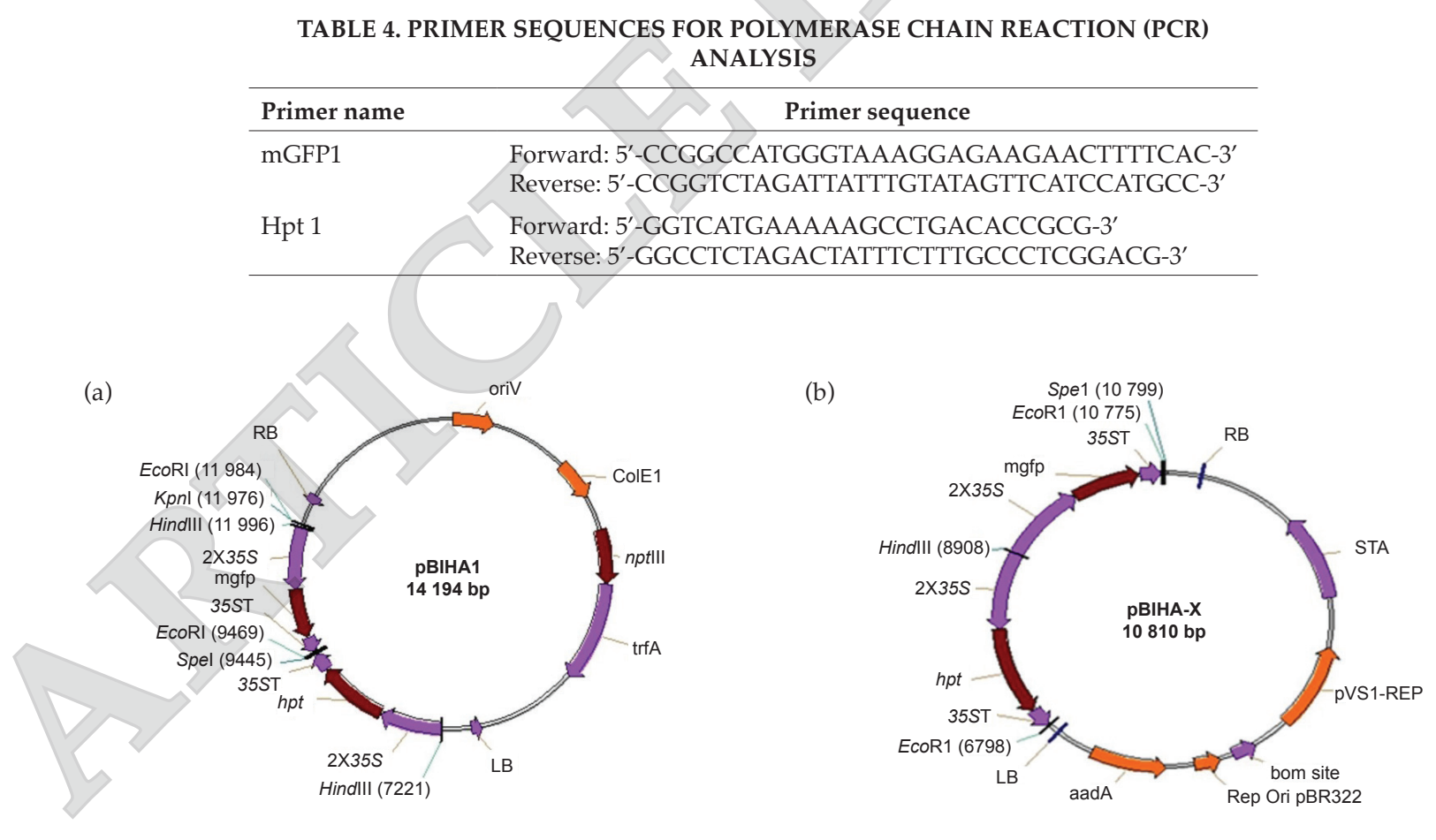

Note: The arrow indicates the orientation of each DNA fragments assembled. LB: left border of T-DNA; 2X35S: double cauliflower mosaic virus $35 S$ promoter; $h p t$ : gene for hygromycin phosphotransferase; mgfp: modified green fluorescent protein; 35ST: $35 S$ terminator gene; RB: right border of T-DNA.

Source: Bahariah et al. (2017).

Figure 1. Schematic diagram of $p B I H A 1$ and $p B I H A-X$ carrying the hpt and gfp genes driven by 2 XCaMV35S assembled in (a) $p B I N P L U S$, and (b) $p C A M B I A$ backbones used for biolistic transformation. 
pCAMBIA0380 backbone $(10.8 \mathrm{~kb})$. The construction was carried out by employing two intermediate plasmids, p2X35STEVHPT-GII (5.5 kb) and p2X35STEVGFP-GII $(5.2 \mathrm{~kb})$, created in the earlier study (Bahariah et al., 2017). The p2X35STEVHPTGII fragment was ligated to the HindIII and EcoRI sites of pCAMBIA0380 to form $8.9 \mathrm{~kb}$ of p2X35STEVHPT-0380. Then, the 2X35STEVHPT fragment of p2X35STEVHPT-0380 was inserted into p2X35STEVGFP-0380 by digestion with HindIII and Spe 1 to produce a vector p2X35STEVHPTGFP-0380, designated as pBIHA-X (Figure 2a). In order to confirm gene insertions into cloning vectors, the vector was analysed by double restriction endonuclease assay using HindIII and EcoR1 (Figure 2b).

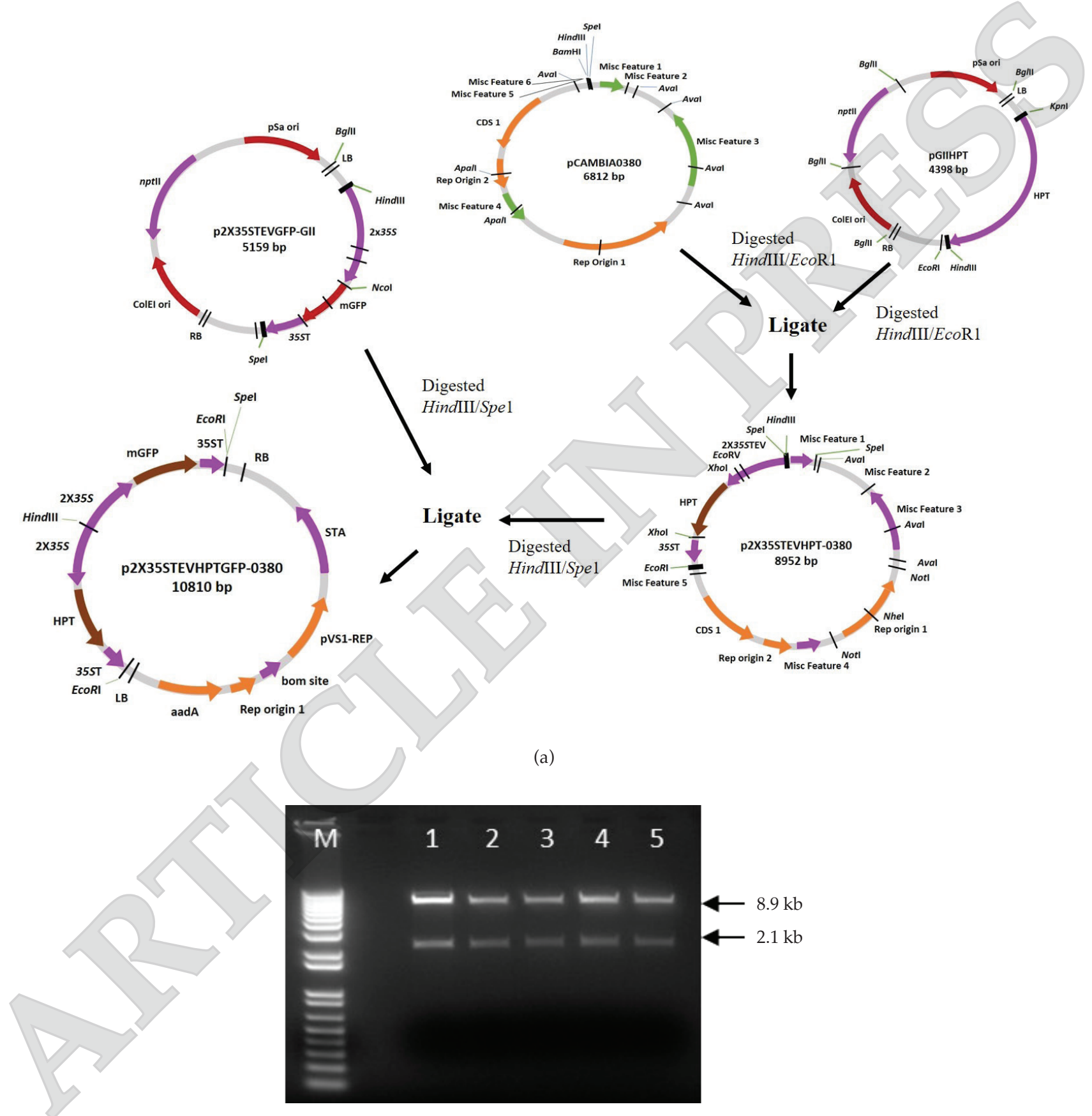

(b)

Figure 2. Construction of pBIHA-X (p2X35SHPTGFP-0380). (a) The gfp reporter gene was released from $p A M C F D V-G F P$ using the HindIII and $\mathrm{NcoI}$ digestion, and ligated into the HindIII and NcoI site of 2X35STEV-PCRIITOPO to create $22 X 35 \mathrm{STEVGFP}$. This was then recombined with hpt gene fragment amplified from $p$ CAMBIA1303 to construct $p 2 X 35 S T E V H P T$. Then, the fragments were digested with HindIII, EcoR1, and cloned into the HindIII and EcoR1 site of pGreenII0000 to generate the p2X35STEVHPT-GII and p2X35STEVGFP-GII. These plasmids were finally ligated to the HindIII and EcoRI sites of $p$ CAMBIA0380 to create $p 2 X 35 S T E V H P T-0380$ and with HindIII and Spe1 to form a vector of p2X35STEVHPTGFP-0380 ( $p B I H A-X)$. (b) Restriction endonuclease analysis of $p B I H A-X$ vector. An equal amount of DNA of each plasmid was digested with HindIII and EcoR1. Lane M: $1 \mathrm{~kb}$ plus DNA ladder, lanes 1-5: Positive clones for p2X35STEVHPT-0380. Arrows indicate the size of 2.1 $k b$ inserted DNA fragment of 2X35S-mGFP-Nos and $8.9 \mathrm{~kb}$ of $\mathrm{p} 2 \mathrm{X} 35 \mathrm{STEVHPT}-0380$. 
The viability of $\mathrm{pBIHA}-\mathrm{X}$ and $\mathrm{pBIHA} 1$ vectors was evaluated by transforming oil palm embryogenic calli using biolistic mediated transformation as described previously (Parveez et al., 2000). After $24 \mathrm{hr}$ post bombardment, the $g f p$ reporter gene expression was visually observed in oil palm calli using AZ100 microscope. The GFP signals were clearly visible in embryogenic calli and reached a peak of more than 30 spots per tissue clump, indicating the $g f p$ gene in both constructed vectors was integrated and expressed in the transformed cells (Figure 3). However, two weeks after bombardment, the number of visible spots expressing $g f p$ declined considerably to less than two spots per clump of tissues with $g f p$ spots grew bigger for some samples. Similar observations were reported in previous studies by Majid and Parveez (2007; 2016). The reduction in the number of GFP spots in oil palm embryogenic calli suggested that GFP degradation and only a few events were stably integrated and expressed. It could also be due to the incidence of transgene silencing mechanisms
(Schubert et al., 2004; Chee et al., 2018). There has been no direct comparison between different vector backbones (pCAMBIA and pBINPLUS) that carry the selectable marker genes. No difference in the GFP expressing cells was observed, suggesting the more prevalent role of the promoter driving the gene as compared to the plasmid backbone (Parveez and Majid, 2008).

Transformed calli were selected in selection medium containing $10 \mathrm{mg} \mathrm{litre}^{-1}$ hygromycin after rested for four weeks. The concentration was chosen based on a previous study on minimal inhibitory concentration (MIC) of hygromycin selection agent for oil palm embryogenic calli (Fakhrana et al., 2019). The study showed that a higher concentration of hygromycin was needed to inhibit the proliferation of embryogenic calli. Therefore, in this study, the embryogenic calli were subcultured every four weeks onto fresh media containing $10 \mathrm{mg}$ litre $^{-1}$ concentration of hygromycin. Early observation found that the development of embryoid and shoots was normal during regeneration of half-

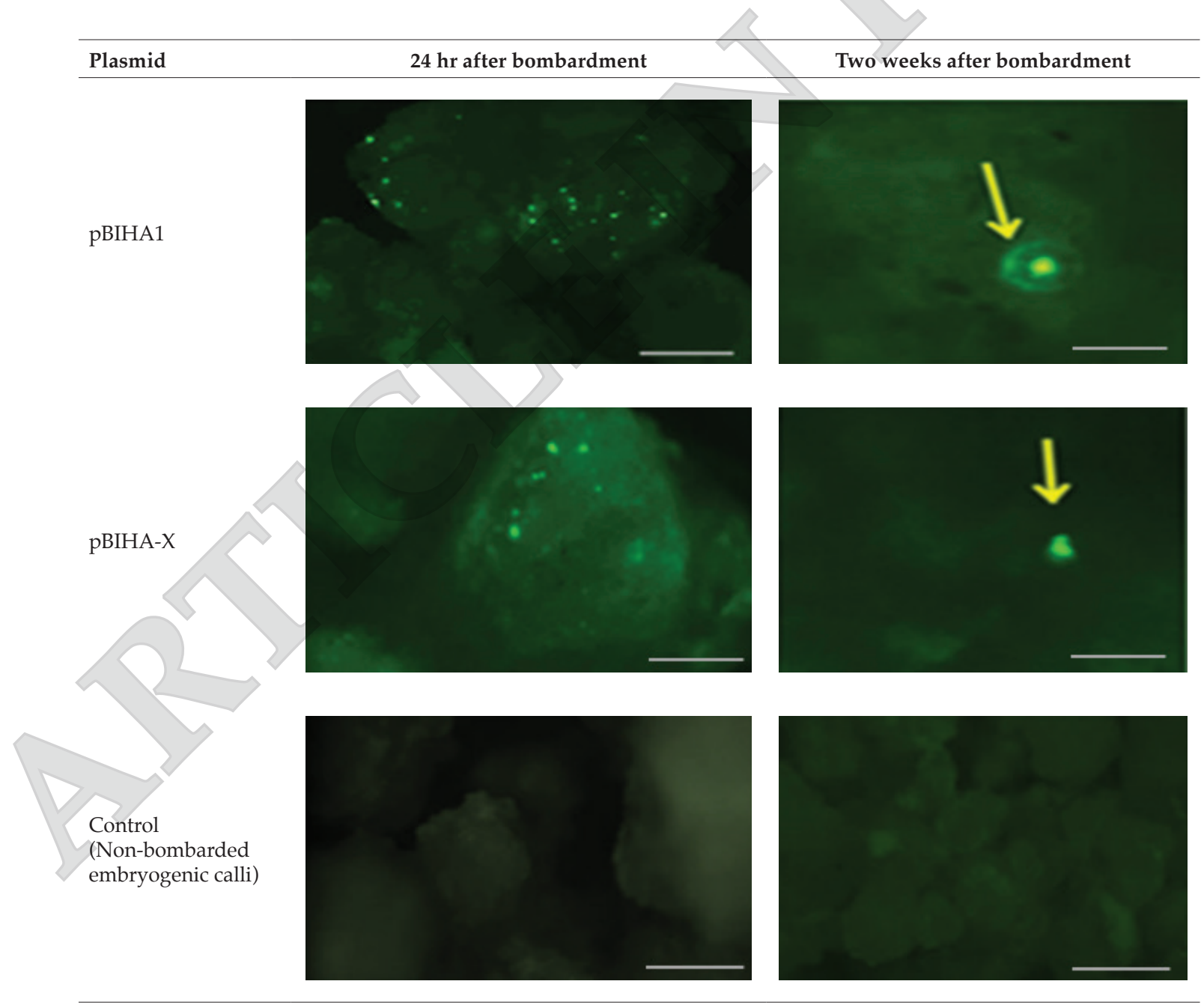

Figure 3. The green fluorescent protein (GFP) expression in transformed oil palm calli at 24 hr and two weeks after bombardment. Transformed tissues expressing GFP and non-bombarded tissues as control are on the right side. Successful transformation of calli bombarded with $p B I H A 1$ plasmid carrying hpt and gfp genes in pBINPLUS backbone; calli bombarded with pBIHA-X plasmid in pCAMBIA backbone. Yellow arrows indicate GFP spots and scale bar equals $10 \mathrm{~mm}(24 \mathrm{hr}$ ) and $20 \mathrm{~mm}$ (two weeks). 
year period. However, after six months of culture, the proliferation was completely stunted and the cultures became necrotic. The embryoid and shoots turned brown and some failed to survive after eight months (Figure 4). The results showed that hygromycin dramatically delayed the inhibition and the growth of oil palm cells at $10 \mathrm{mg} \mathrm{litre}^{-1}$ selection concentration. This observation suggested that oil palm embryogenic calli are highly sensitive to the hygromycin. This finding is consistent with previous studies that showed the presence of antibiotic selection pressures at exceeding maximum levels could inhibit the growth of the transformed plants and kill the nontransformed cells, thus, leading to delay in regeneration (Wilmink and Dons 1993). Subsequently, we then utilised stepwise decreasing concentration of hygromycin from 10 to $5 \mathrm{mg} \mathrm{litre}^{-1}$ at nine months. The hygromycin concentration at $5 \mathrm{mg}$ litre $^{-1}$ was used as in agreement of an earlier study by Fakhrana et al. (2019). The study showed the concentration of hygromycin needs to gradually decrease throughout the callus maturation process to allow the transformed cells to regenerate to normal plants (Fakhrana et al., 2019). Similar observations were reported in Setaria viritis (Van Eck et al., 2017) and wheat (Gils, 2017).

To investigate the presence of the hpt gene in transformed oil palm tissue, genomic DNA from regenerated embryoid was used for PCR analysis using a specific hpt primers (Table 4). The result of the PCR analysis is shown in Figure 5. Seven plants out of 33 samples tested, were positive for hpt gene $(21 \%)$. From the results obtained, $27 \%$ of the samples bombarded with pBIHA1 vector and $18 \%$ of the samples bombarded with pBIHA-X were $h p t$ positive. The results showed that a $1000 \mathrm{bp}$ fragment of hpt gene was successfully amplified. These positive DNA samples were later subjected to PCR amplification using primers specific for $g f p$ gene. A total of five out of seven hpt positive samples tested were able to amplify the $450 \mathrm{bp} g f p$ gene fragment (Figure 6). The results indicated that only five lines were confirmed to carry both transgenes, $g f p$ and $h p t$, while the other 26 lines did not show any PCR product. These results could further support the presence of gene escapes due to the chimeric nature of these lines or incomplete insertion of the target genes into the plant genome.

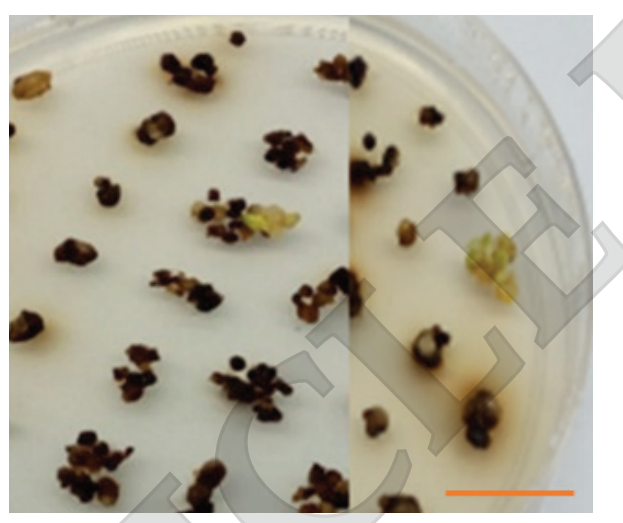

(a)

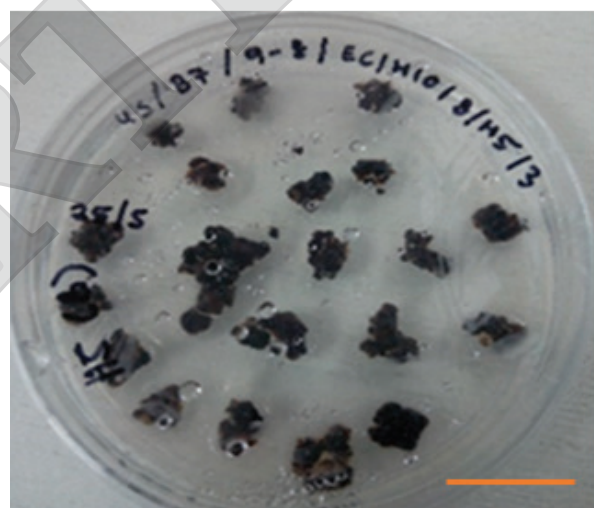

(c)

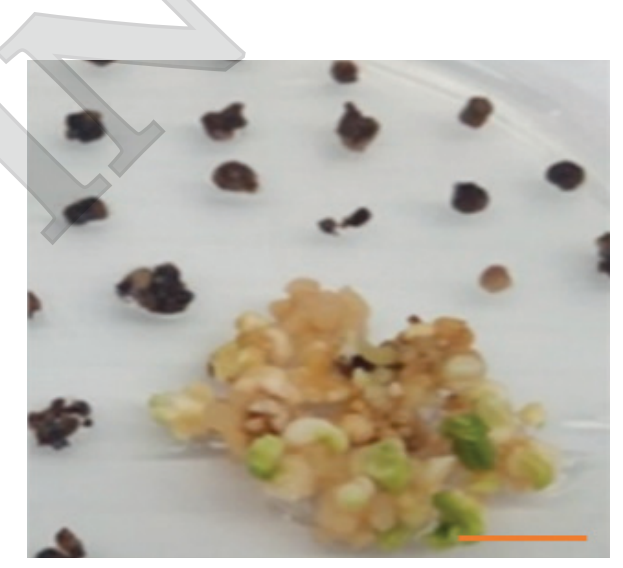

(b)

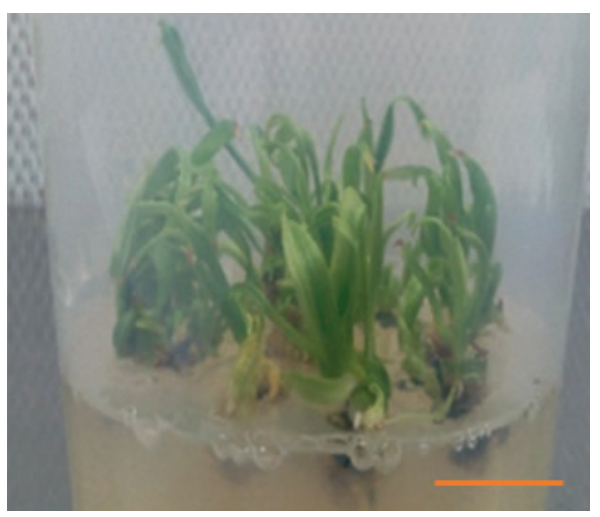

(d)

Figure 4. The bombarded calli with $p B I H A-X$ plasmid grown on media containing hygromycin selection agent. (a) Oil palm calli were selected on $10 \mathrm{mg}$ litre-1 hygromycin media for eight months (b) at three months after decreasing to $5 \mathrm{mg}$ litre-1 hygromycin, (c) non-bombarded calli in selection medium and (d) non-bombarded calli on medium without selection. Yellowish and greenish were observed for the transformant $(a, b)$, while for the untransformed cells turn black (c). Scale bar: a (bar $1 \mathrm{~cm}), b($ bar $4 \mathrm{~mm}), c($ bar $1 \mathrm{~cm})$ and $d(b a r 2 \mathrm{~cm})$. 
(a)

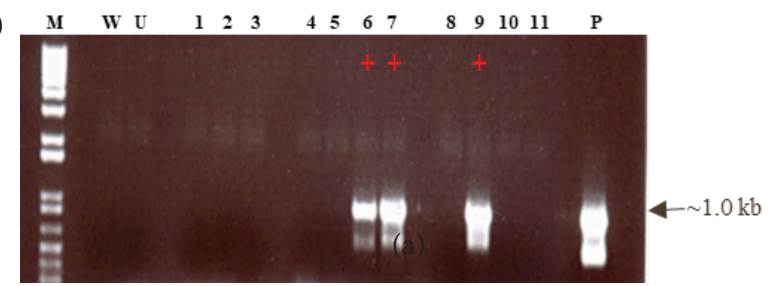

(b)

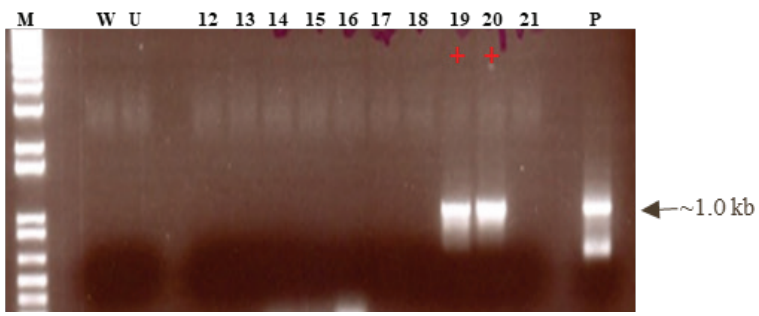

(c)

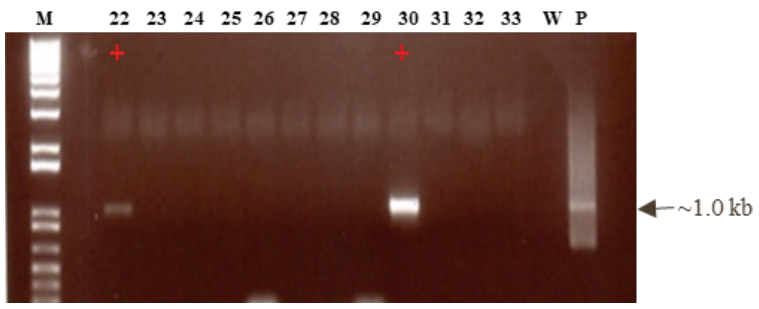

Figure 5. Polymerase chain reaction (PCR) analysis of the putative transgenic embryoid bombarded with plasmids, pBIHA1 (a) and pBIHA-X $(b, c)$ to detect the presence of hpt gene. Lane M: $1 \mathrm{~kb}$ plus marker ladder; lane W: water as negative control; lane $U$ : untransformed plants; lane P: positive control ( $p B I H A-X)$; lanes 1-33: transformed plants and lanes 6, 7, 9, 19, 20, 22, 30 were positive amplified a $1 \mathrm{~kb}$ DNA fragment using primers corresponding to a hpt gene.

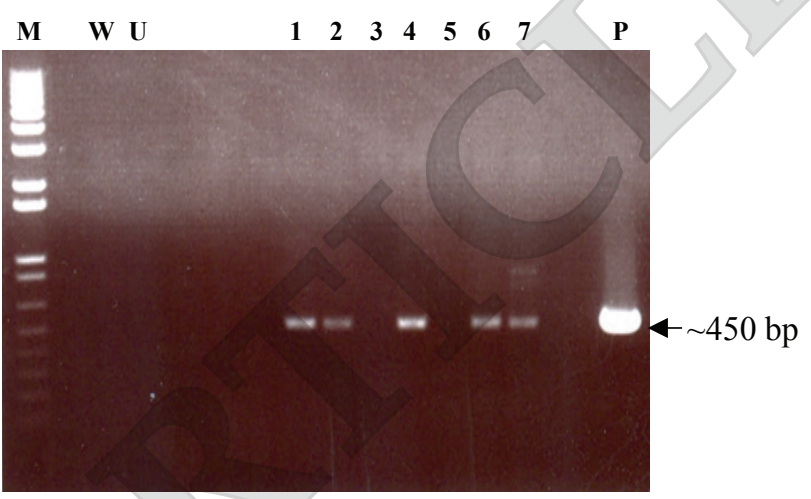

Figure 6. Polymerase chain reaction (PCR) analysis of genomic DNA from putative green fluorescent protein (GFP) transformed oil palm calli to detect the presence of gfp gene. PCR amplified a $450 \mathrm{bp}$ fragment using $m$ GFP1F/R primers. Lane M: $1 \mathrm{~kb}$ plus marker ladder; P: positive control ( $p B I H A-X)$; U: untransformed plants, $W$ : water as negative control; 1-7: transformed plants.

Overall, the study demonstrated the suitability of the $h p t$ gene in both vectors, $\mathrm{pBIHA}-\mathrm{X}$ and $\mathrm{pBIHA} 1$ for biolistic transformation of oil palm. Both vectors were driven by the same promoter, the double enhanced CaMV35S promoter, which was amplified from pCAMBIA1303. Previously, the CaMV35S promoter was found to be the most effective promoter for driving $g f p$ gene in oil palm tissues (Parveez and Majid, 2008). The vectors transformed to express the $g f p$ gene and stable integration of both $g f p$ and $h p t$ transgenes into oil palm embryogenic calli was detected by PCR and transient expression assay. A low concentration of selection agent may be required for callus regeneration. The concentration of $10 \mathrm{mg}$ litre $^{-1}$ is probably too high for selection. This will not only kill the nontransformed cells but also result in toxicity that might inhibit the growth of transformed cells. Some species are very sensitive to hygromycin and only a low concentration was used for their transformant selection, such as 3.0 $\mathrm{mg}$ litre $^{-1}$ for rapeseed leaf petiole cells (Liu et al., 2011) and $7.5 \mathrm{mg}$ litre $^{-1}$ for Centaurea montana leaf explants (Abou-Alaiwi et al., 2012). The sensitivity of plant tissues to the selective agent depends on many factors, including the tissue types, size of explants, developmental stage, chemical properties and concentration of the selective agents (Bowen, 1993). This could lead to variation in the optimal concentration for selection between plant species. For example, the hygromycin concentration at $25 \mathrm{mg}$ litre $^{-1}$ for S. viridis (Van Eck, 2018), $50 \mathrm{mg} \mathrm{litre}^{-1}$ for banana (Barlett et al., 2008), $20 \mathrm{mg}$ litre $^{-1}$ for cotton (Meng et al., 2007) and $30 \mathrm{mg}$ litre ${ }^{-1}$ for rice (Kumar et al., 2005) were determined to be the optimal concentration of this selective agent. In addition, the selection system to differentiate transformed and nontransformed cells are requisite to regenerate the truly genetically transformed cell.

\section{CONCLUSION}

The production of transgenic oil palm is difficult and time-consuming. An alternative approach to tighten the selection system for stable transformation of oil palm was evaluated using an antibiotic hygromycin selectable marker gene, which might be useful and efficient to address these challenges. Oil palm embryogenic calli were bombarded with plasmids carrying $h p t$ selectable marker and $g f p$ reporter genes and selected on medium containing hygromycin. The GFP expression was detected on the transformed tissues that survived the selection, indicating successful transformation. Successful regeneration of the bombarded tissues was achieved through the application of stepwise decreasing concentration of hygromycin selection from 10 to $5 \mathrm{mg}$ litre $^{-1}$. The non-bombarded embryogenic calli were completely stunted and became necrotic. The regenerated transgenic plants were confirmed through PCR. The rate of $h p t$ positive plants was at $21 \%$. The majority of these $h p t$ positive plants were also shown to carry $g f p$ transgene. Expression studies of the $h p t$ and $g f p$ genes in transgenic oil palm will be carried out to assess the expression level of the transgenes. In 
addition, the integration of the transgenes will also be verified to further confirm their integration and copy number in the regenerated plants.

\section{ACKNOWLEDGEMENT}

The authors would like to thank the MPOB for permission to publish this article. We also would like to acknowledge Mrs Nurul Huda Ideris and all members of the Transgenic Technology Laboratory of MPOB for their assistance.

\section{REFERENCES}

Abdullah, R; Zainal, A; Heng, W Y; Li, L C; Beng, Y C; Phing, L M; Sirajuddin, S A; Ping, W Y S and Joseph, J L (2005). Immature embryo: A useful tool for oil palm (Elaeis guineensis Jacq.) genetic transformation studies. Electronic. J. Biotechnol., 18: 24-34.

Abou-Alaiwi, W A; Potlakayala, S D; Goldman, S L; Josekutty, P C; Karelia, D N and Rudrabhatla, S V (2012). Agrobacterium-mediated transformation of the medicinal plant Centaurea montana. Plant Cell Tissue Organ Cult. DOI:10.1007/s11240-011-0067-8.

Bahariah, B; Masani, M Y A; Parveez, G K A and Rasid, O A (2017). Construction of a vector containing hygromycin (HPT) gene driven by double 35S (2XCAMV35S) promoter for oil palm transformation. J. Oil Palm Res. Vol. 29(2): 180-188.

Barlett, J G; Alves, S C; Smedley, M; Snape, J W and Harwood, W A (2008). High-throughput Agrobacterium-mediated barley transformation. Plant Meth., 4(1): 22 pp.

Belknap, R W; Rockhold, R D and McCue, K F (2008). pBINPLUS/ARS: An improved plant transformation vector based on pBINPLUS. BioTechniques, 44: 753756.

Bhore, S J and Shah, F H (2012). Genetic transformation of the American oil palm (Elaeis oleifera) immature zygotic embryos with antisense palmitoyl-acyl carrier protein thioesterase (PATE) gene. World Appl. Sci. J., 16: 362-369.

Bowen, B A (1993). Markers for plant gene transfer. Transgenic Plants (Kung, S and Wu, R eds.). Academic Press Inc., San Diego, USA. p. 89-123.

Chee, M J Y; Lycett, G W and Chin, C F (2018). Development of a direct transformation method by GFP screening and in vitro whole plant regeneration of Capsicum frutescens L. Electron J. Biotechnol., 34: 5158.
De Block, M; Botterman, J; Vandewiele, M; Dockx, J; Thoen, C; Gossele, V; Movva, R; Thompson, C; Van Montagu, M and Leemans, J (1987). Engineering herbicide resistance in plants by expression of a detoxifying enzyme. EMBO J., 6: 2513-2518.

Fan, C; Pu, N; Wang, X; Wang, Y; Fang, L; Xu, $\mathrm{W}$ et al (2008). Agrobacterium-mediated genetic transformation of grapevine (Vitis vinifera L.) with a novel stilbene synthase gene from Chinese wild Vitis pseudoreticulata. Plant Cell Tissue Organ Cult., 92: 197-206.

Fakhrana, I N; Nurfahisza, A R; Rasid, O A and Parveez, G K A (2019). Minimal inhibitory concentration of hygromycin for selecting transformed oil palm embryogenic calli. J. Oil Palm Res. Vol. 31(1): 14-27.

Gils, M (2017). A recessive pollination control system for wheat based on intein-mediated protein splicing. Split Inteins: Methods and Protocols, Methods in Molecular Biology (Mootz, H D ed.). Humana Press, New York, USA. p. 173-195.

Gonzalez, A; Jimenez, A; Vazquez, D; Davies, J E and Schindler, D (1978). Studies on the mode of action of hygromycin B, an inhibitor of translocation in eukaryotes. Biochim. Biophys. Acta. 521: 459-469.

Gritz, L and Davies, J (1983). Plasmid-encoded hygromycin B resistance: The sequence of hygromycin B phosphotransferase gene and its expression in Escherichia coli and Saccharomyces cerevisiae. Gene, 25(2-3): 179-188.

Hajdukiewicz, P; Svab, Z and Maliga, P (1994). The small, versatile $p P Z P$ family of Agrobacterium binary vectors for plant transformation. Plant Mol. Biol., 25: 989-994.

Kalawong, S and Te-chato, S (2012). Factors affecting gene transformation in embryogenic callus of oil palm by bombardment technique. J. Agricultural Technology, 8(7): 2373-2384.

Kanchanapoom, K; Nakkaew, A; Kanchanapoom, $\mathrm{K}$ and Phongdara, A (2008). Determination of the most efficient target tissue and helium pressure for biolistic transformation of oil palm (Elaeis guineensis Jacq.). Songklanakarin J. Sci. Technol., 30(2): 151-157.

Kumar, K; Maruthasalam, S; Loganathan, M; Sudhakar, D and Balasubramanian, P (2005). An improved Agrobacterium-mediated transformation protocol for recalcitrant elite indica rice cultivars. Plant Mol. Biol. Rep., 23: 67-73. 
Liu, H; Guo, X; Naeem, M S; Liu, D; Xu, L; Zhang, W; Tang, G and Zhou, W (2011). Transgenic Brassica napus L. lines carrying a two gene construct demonstrate enhanced resistance against Plutella xylostella and Sclerotinia sclerotiorum. Plant Cell Tissue Organ Cult., 106: 143-151.

Masani, M Y A; Noll, G A; Parveez, G K A; Sambanthamurthi, R and Prüfer, D (2014). Efficient transformation of oil palm protoplasts by PEGmediated transfection and DNA microinjection. PLOS ONE, 9(5): e96831.

Masli, D I A; Parveez, G KA and Yunus, AM M (2009). Transformation of oil palm using Agrobacterium tumefaciens. J. Oil Palm Res. Vol. 21: 643-652.

Masura, S S; Tahir, N I; Rasid, O A; Ramli, U S; Othman, A; Masani, M Y A; Parveez, G K A and Kushairi, A (2017). Post-genomic technologies for the advancement of oil palm research. J. Oil Palm Res. Vol. 29(4): 469-486.

Majid, N A and Parveez, G K A (2016). Regeneration of transgenic oil palm carrying $g f p$ gene used as a visual selectable marker. J. Oil Palm Res. Vol. 28(4): 415-430.

Majid, N A and Parveez, G K A (2007). Evaluation of green fluorescent protein (GFP) as a selectable marker for oil palm transformation via transient expression. Asia Pac. J. Mol. Biol. Biotech., 15(1): 1-8.

Meng, Z H; Liang, A H and Yang, W C (2007). Effects of hygromycin on cotton cultures and its application in Agrobacterium-mediated cotton transformation. In vitro Cell Develop Biol Plant., 43: 111-118.

Milojević, J; Tubić, L; Nolić, V; Mitić, N; CalićDragosavac, D; Vinterhalter, B and Zdravkovic'Korac, S (2012). Hygromycin promotes somatic embryogenesis in spinach. Plant Cell Tissue Organ Cult., 109: 573-579.

Murakami, T; Anzai, H; Imai, S; Satoh, A; Nagaoka, $\mathrm{K}$ and Thompson, C J (1986). The bialaphos biosynthetic genes of Streptomyces hygroscopicus: Molecular cloning and characterisation of the gene cluster. Mol. Gen. Genet., 205: 42-50.

Murashige, T and Skoog, F (1962). A revised medium for rapid growth and bioassays with tobacco tissue cultures. Physiol. Plant., 15: 473-497.

Norrander, J; Kempe, T and Messing, J (1983). Construction of improved M13 vectors using oligodeoxynucleotide-directed mutagenesis. J. Gene., 26(1): 101-106.
Nurfahisza, A R; Rafiqah, M A; Masani, M Y A; Nor Hanin, A A; Rasid, O A; Parveez, G K A and Ismanizan, I (2014). Molecular analysis of transgenic oil palm to detect the presence of transgenes. J. Oil Palm Res. Vol. 26: 73-80.

Parveez, G K A (2000). Production of transgenic oil palm (Elaeis guineensis Jacq.) using biolistic techniques. Molecular Biology of Woody Plants (Jain, S M and Minocha, S C eds.). Kluwer Academic Publishers. Dordrecht, 2: 327-350.

Parveez, G K A and Majid, N A (2008). Factors affecting green fluorescence protein (GFP) gene expression in oil palm after microprojectile bombardment mediated transformation. J. Oil Palm Res. Vol. 20: 495-507.

Parveez, G K A; Rasid, O A; Masani, M Y A and Sambanthamurthi, R (2015). Biotechnology of oil palm: Strategies towards manipulation of lipid content and composition. Plant Cell Rep., 34: 533543.

Parveez, G K A; Majid, N A; Zainal, A and Rasid, O (2007). Determination of minimal inhibitory concentration of selection agents for selecting transformed immature embryos of oil palm. Asia Pac. J. Mol. Biol. Biotechnol., 15(3): 133-146.

Parveez, G K A; Masri, M M; Zainal, A; Majid, N A; Yunus, A M M; Fadilah, H H; Rasid, $\mathrm{O}$ and Cheah, S C (2000). Transgenic oil palm: Production and projection. Biochem. Soc. T., 28(6): 969-972.

Parveez, G K A; Chowdhury, M K U and Saleh, N M (1996). Determination of minimal inhibitory concentration of selection agents for oil palm (Elaeis guineensis Jacq.) transformation. Asia Pacific J. Molecular Biology and Biotechnology, 4: 219-228.

Paz, M M; Shou, H X; Guo, Z B; Zhang, Z Y; Banerjee, A K and Wang, K (2004). Assessment of conditions affecting Agrobacterium-mediated soybean transformation using the cotyledonary node explant. Euphytica, 136(2): 167-179.

Schubert, D; Lechtenberg, B; Forsbach, A; Gils, M; Bahadur, S and Schmidt, R (2004). Silencing in Arabidopsis T-DNA transformants: The predominant role of a gene-specific RNA sensing mechanism versus position effects. The Plant Cell, 16(10): 25612572 .

Sujatha, M and Sailaja, M (2005). Stable genetic transformation of castor (Ricinus communis L.) via Agrobacterium tumefaciens-mediated gene transfer using embryo axes from mature seeds. Plant Cell Rep., 23: 803-810. 
Suwanaketchanatit, C; Piluek, J; Peyachoknagu, S and Huehne, P S (2007). High efficiency of stable genetic transformation in Dendrobium via microprojectile bombardment. Biol. Plant., 51: 720727.

Thompson, C J; Rao Movva, N; Tizard, R; Crameri, R; Davies, J E; Lauwereys, $\mathrm{M}$ and Botterman, J (1987). Characterisation of the herbicide resistance gene bar from Streptomyces hygroscopicus. EMBO J., 6: 2519-2523.

Van Eck, J (2018). The status of Setaria viridis transformation: Agrobacterium-mediated to floral dip. Front. Plant Sci., 9: 652 pp.

Van Eck, J; Swartwood, K; Pidgeon, K and MaxsonStein, K (2017). Agrobacterium tumefaciens-mediated transformation of Setaria viridis. Genetics and Genomics of Setaria (Doust, A and Diao, X eds.). Cham, Springer. p. 343-356.

Wilmink, A and Dons, J J M (1993). Selective agents and marker genes for use in transformation of monocotyledonous plant. Plant Mol. Biol. Rep., 11: 165-185.

Zhang, P and Puonti-Kaerlas, J (2000). PIG-mediated cassava transformation using positive and negative selection. Plant Cell Rep., 19: 1041-1048.

Zulkifli, Y; Norziha, A; Naqiuddin, M H; Fadila, A M; Nor Azwani, A B; Suzana, M; Samsul, K R; OngAbdullah, M; Singh, R; Parveez, G KA and Kushairi, A (2018). Designing the oil palm of the future. J. Oil Palm Res. Vol. 29: 440-445. 